REPORTS OF MORPHOLOGY
$\begin{gathered}\text { Official Journal of the Scientific Society of Anatomists, } \\ \text { Histologists, Embryologists and Topographic Anatomists } \\ \text { of Ukraine } \\ \text { journal homepage: https://morphology-journal.com }\end{gathered}$

\title{
Morphological changes of a great omentum at implantation of polypropylene and composite prostheses at allohernioplasty
}

\section{Vorovskyi O.O., Shaprynskyi V.O., Sadyk I.M.}

National Pirogov Memorial Medical University, Vinnytsya, Ukraine

\section{ARTICLE INFO}

Received: 9 October, 2019

Accepted: 10 November, 2019

UDC: $616.382 .1: 617.55-007.43-$

089.844:616-77

\section{CORRESPONDING AUTHOR}

e-mail: vorovskiysurgery@ukr.net Vorovskyi O.O.
To date, allohernioplasty of giant postoperative ventral hernias retains high postoperative mortality and a significant number of postoperative complications. The purpose of the study is to investigate the possibility of intraperitoneal use of polypropylene and composite implants in allohernioplasty of postoperative giant ventral hernias by studying the morphological changes of the great omentum. The results of surgical treatment of 146 patients with postoperative giant ventral hernias were investigated. To this group of patients with allohernioplasty by the method onlay was performed $22(15.1 \%)$ patients, by the method sublay - 46 (31.5\%), by the method inlay - 52 (35.6\%), with intraabdominal placement of the mesh by the method onlay (intraperitoneal onlay mesh) $26(17.8 \%) .32(21.9 \%)$ patients who underwent surgery using the sublay method polypropylene implant was fenced off from the abdominal organs with a great omentum, $22(15.1 \%)$ patients operated on by the intraperitoneal onlay mesh method composite implant was also fenced off from the abdominal organs by a great omentum. In 8 (5.5\%) patients from the group of patients who were operated on by the sublay method and in $6(4.1 \%)$ - operated by the intraperitoneal onlay mesh method for 14-18 days patients developed signs of chronic intestinal obstruction, where the cause was postoperative adhesive illness. The study of the effect of polypropylene prosthesis on a great omentum was performed on 8 outbred dogs and 6 outbred mature dogs, who were implanted with a composite mesh unilaterally covered with oxycellulose. The polypropylene implant has been shown to have a greater capacity for the development of adhesive processes. However, if a great omentum to protect this prosthesis from the abdominal cavity then the first zone (active inflammation) spread in 155 microns (increase in the number of blood capillaries of the microcirculatory bed, thickening of the arterioles wall, venous full blood flow, diapedesis of leukocytes through the wall of the blood cells), the second zone (sclerosis) - up to 40 microns (increase in the number of macrophages and lymphocytes. proliferation of fibroblasts). In the future, the structure of the omentum was almost indistinguishable, so with allohernioplasty by the developed method, it was possible to prevent the development of adhesive disease on the intestine. This study confirmed the limited spread of the inflammatory response, which allows the implant of a polypropylene mesh on a great omentum. In the composite mesh, the composite mesh was spliced with surrounding tissues from the side where there was no gel coating, and from the side of the salivary coating, the "readiness" to spread the inflammatory process (vasculitis with pronounced lympho-plasmocytic infiltration of the vessel walls and perivascular ductus), therefore, left it is also necessary to enclose it with a large omentum from intestium.

Keywords: polypropylene prosthesis, composite mesh, allohernioplasty, great omentum.

\section{Introduction}

The incidence of postoperative ventral hernias after laparotomy, according to various authors, is from $10 \%$ to $30 \%$ [1]. According to many researchers, a special place is occupied by defects of large and giant size, involving two or more sections of the abdominal wall, make up $18-45 \%$ [9, 13]. Of particular concern to surgeons is the degree of destruction of the anatomical structures of the abdominal wall, which can be considered a real " catastrophe " when 
conducting reconstructive operations. First of all, this is due to the fact that the scar formation in the area of hernial defect runs parallel to the atrophic degenerative processes in the muscles and fascial-aponeurotic structures of the abdominal wall [5]. According to some authors, the use of auxiliary materials has allowed to significantly improve the results of treatment of patients with giant postoperative ventral hernias [2, 12]. However, with different methods of alloplasty, the recurrence of the disease ranges from $10 \%$ to $20 \%$ [8].

However, there are studies that state that synthetic tissue introduced into the body still remains a "foreign" body to it. The possibility of contact of the implanted prosthesis with the intestine remains unexplored, and as a result there is a risk of splicing with the intestine and impaired patency [3]. Also, some surgeons have noted that the above methods of alloplasty have a common disadvantage, because they do not consider the need to attach the prosthesis to the tendon fixation of the abdominal wall muscles, and thus exclude the pathogenetic aspect of restoration of function [5] in cases where the location of polypropylene implant in the retromuscular or preperitoneal space was impossible $[14,18]$. To solve these problems, consider the choice of a method of intraperitoneal plastics - an alternative option of closing the defects of the abdominal wall with localization $M$ and $L$ (according to the classification Chevrel - Rath) [7]. The use of composite materials has become widespread [16].

The purpose of the study is to investigate the possibility of intraperitoneal use of polypropylene and composite implants in allohernioplasty of postoperative giant ventral hernias by studying the morphological changes of the great omentum.

\section{Materials and methods}

For the period 2002-2018 at the Department of Surgery №1, 146 patients with postoperative giant ventral hernias were operated (according to the classification of J.P. Chevrel and A.M. Rath). The age of patients ranged from 40 to 88 years. This group of patients with allohernioplasty was performed by the method onlay $22(15.1 \%)$, sublay - 46 (31.5\%), inlay - 52 (35.6\%), IPOM - 26 (17.8\%). Preference was given to operations that did not reduce abdominal volume. Of the $46(31.5 \%)$ patients operated on by the sublay method, $32(21.9 \%)$ patients with a polypropylene implant ("Ukrainian chain mail", "Lintex") were fenced off from the abdominal cavity by great omentum. Of the 26 $(17.8 \%)$ patients operated on by the IPOM method, 22 (15.1\%) patients used a composite implant ("Proseed"), which was also fenced off from the abdominal cavity by great omentum. In $8(5.5 \%)$ patients from the group of patients operated on the sublay method and in $6(4.1 \%)$ operated on the IPOM method, signs of chronic intestinal obstruction developed on 14-18 days, where postoperative adhesive disease became the cause.

To determine this reason, it was decided to conduct an experimental study. Experimental studies selected 14 outbred dogs. The experiment obtained permission of the Commission on Bioethics National Pirogov Memorial Medical University, Vinnytsya (protocol №1 of 13.01.2011), which established that the conducted studies meet the ethical and moral requirements in accordance with the order of the Ministry of Health of Ukraine №281 of 01.11.2000. During the research, the basic rules of good laboratory practice GLP (1981), Law of Ukraine №3447-IV "On the Protection of Animals against Cruelty" of 21.02.2006 were followed. The experiment was carried out in accordance with the standards of the Council of Europe Convention on Bioethics (1997), the World Health Association Declaration of Helsinki (1996), the European Convention for the Protection of Vertebrate Animals used for experimental and other scientific purposes (1985). The operative part of the experiment was performed in the operating room with all the requirements of asepsis. After surgery, the animals were kept in the vivarium on a standard diet. There was no harm to the dogs' health.

From the selected experimental material were cut fragments of tissue $1 \times 1 \times 0.5 \mathrm{~cm}$ so that the block had implants and a great omentum with a border between them. Similarly, sized tissue fragments were obtained from the clinical operating material, which was fully analyzed. For fixation of tissues used a $10 \%$ solution of neutral formalin. After dehydration according to the standard scheme, paraffin blocks were made, sections of which 5-7 $\mu \mathrm{m}$ thick were examined by histological methods (staining with hematoxylin and eosin, as well as by Van Gieson and Verhoff methods). Separate histochemical techniques have been used to verify certain chemical compounds in tissue structures, as described in the relevant guidelines. For the verification of protein-synthesizing cells (in particular immunocompetent) used the Brasche reaction. The presence of glycogen and glycoproteins was determined by the method of PAS reaction, lipofuscin - by the method of detection of acid-resistant lipofuscin in semi-thin sections according to Ziehl-Nielsen.

Preparations were viewed under the OLYMPUSBX 41 microscope at magnifications of 40, 100, 200 and 400. Photographs of the microproducts were performed using a video system and a licensed Olympus Quick Photo Micro 2.3 software using an Olympus E-410 digital camera.

The morphological study of the effect of polypropylene mesh on a great omentum was performed on 8 outbred dogs, which were divided into 2 groups. The control group consisted of 2 dogs who had a laparotomy and were taken biopsy from a great omentum. In the study group (6 animals), a laparotomy was performed with simultaneous modeling of the defect of the parietal peritoneum, where a polypropylene mesh was sewn, the strand being sewn to a great omentum. Further, a relaparotomy was performed to collect the biopsy specimen from the great omentum at the point of its adherence to the mesh. Two dogs were reoperated after 1 week, 2 dogs after 2 weeks, and 2 dogs 
after 3 weeks.

We also conducted an experimental study of the effect of alloprosthetics composite mesh on the great omentum and intestine. To find out the effectiveness of different ways of strengthening the abdominal wall and their possible complications during surgical treatment of hernias, an experiment was conducted on 6 outbred sexually mature dogs, which were implanted with polypropylene mesh unilaterally covered with oxycellulose. The material for pathohistological examination was obtained during the following operations 3 weeks later and 3 months after the first surgery.

\section{Results}

Morphological study of the effect of polypropylene mesh on a great omentum. One week after surgery, in 6 outbred dogs were allocated 2 zones on histological preparations of the omentum: 1 - the omental area, which was directly adjacent to the mesh, up to $40 \mu \mathrm{m}$ thick with signs of inflammatory processes; 2 - the zone of the omentum adjacent to the intestine was virtually unchanged.

In the first zone, the following phenomena were observed: increase in the number of vessels of the microcirculatory bed, arterial and venous plethora, thickening of the walls of arterioles and venules, marginal placement of leukocytes in venules, diapedesis of leukocytes through the walls of venules and capillaries. The lumen of the lymphatic capillaries was greatly expanded. The connective tissue contains neutrophils, macrophages, lymphocytes, tissue basophils, giant macrophages. The proliferation of fibroblasts and the growth of collagen fibers were expressed, especially the concentration of these cells around the vessels of the microcirculatory bed.

In the second zone, there was a slight increase in collagen fibers (Fig. 1). The structure of the omentum in this area did not differ from the structure of the omentum of intact animals. A slight thickening of collagen fibers was found.

After 2 weeks after surgery, the first zone expanded significantly - up to $120 \mu \mathrm{m}$. The growth of fibroblasts and fibrocytes, coarse fibrous scar tissue was observed, and the number of vessels of the microcirculatory bed with pronounced venous plethora was significantly increased (Fig. 2). Accumulations of macrophages, lymphocytes, and lymphoblasts, which were similar in structure to lymphatic follicles, were also established (Fig. 3).

In the second zone, venous plethora, thickening and fibrosis of the walls of the arterioles were observed and their lumen was reduced compared to the norm. The lymphatic capillaries were enlarged. Against the background of increasing numbers of macrophages and lymphocytes, fibroblast proliferation occurred.

At the boundary of these areas was noted area of tender sclerosis. It observed infiltration of the interstitium by macrophages and lymphocytes, as well as single tissue basophils, proliferation of fibroblasts and growth of collagen fibers (Fig. 4).

3 weeks after surgery, there is a significant expansion of the first zone to 140-155 microns and an increase in the number of blood vessels in the microcirculatory bed; enlargement of the lumen of the lymphatic vessels, gross

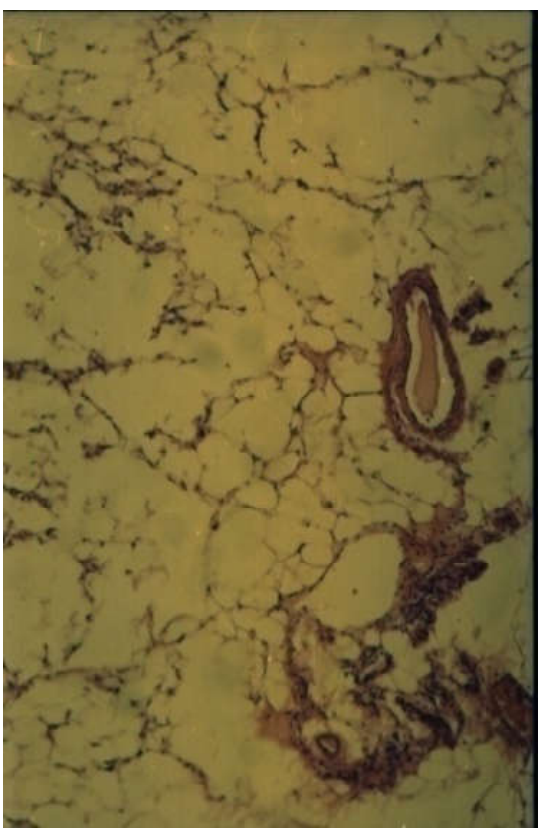

Fig. 1. The concentration of collagen fibers around the vessels of the microcirculatory bed (yellow arrow). Hematoxylin-eosin, $\mathrm{x} 100$.

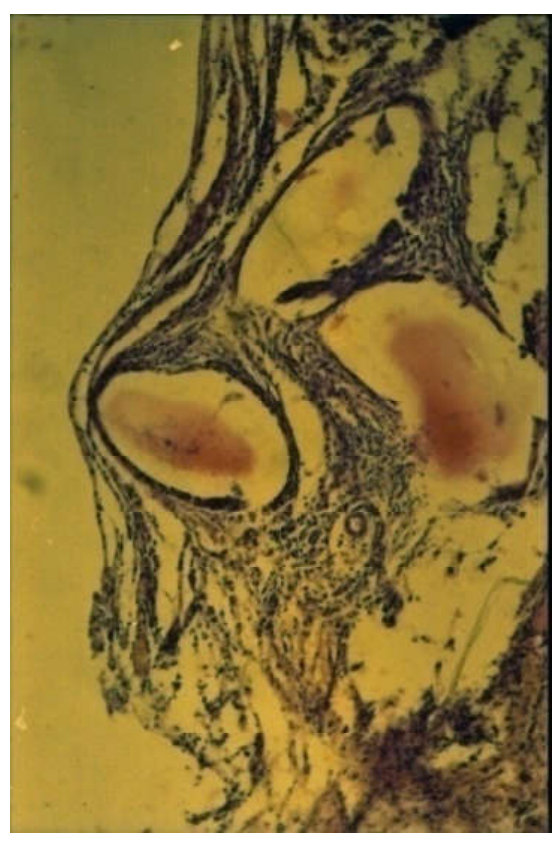

Fig. 2. Venous plethora on the background of the growth of coarse fibrous connective tissue (yellow arrows). Hematoxylin-eosin, $\mathrm{x} 100$.

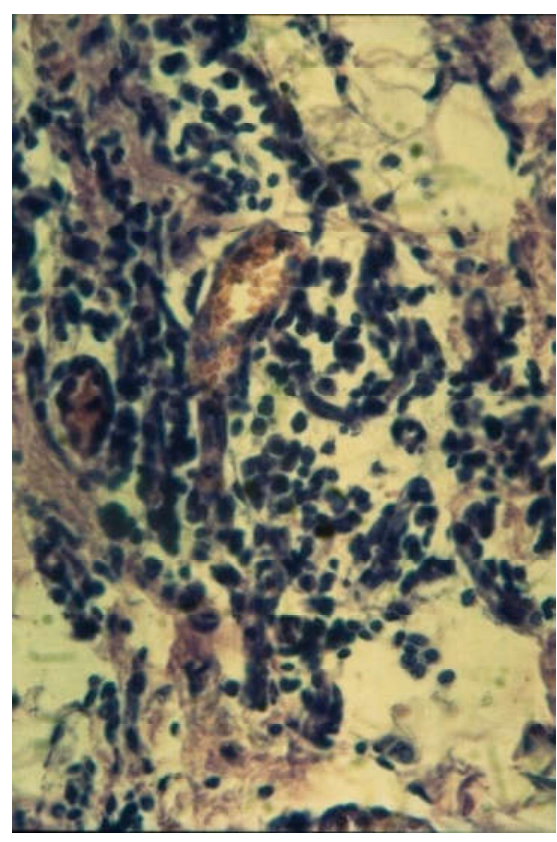

Fig. 3. The accumulation of neutrophils, macrophages, lymphocytes and tissue basophilia is more pronounced around the vessels (yellow arrow). Hematoxylin-eosin, x200. 

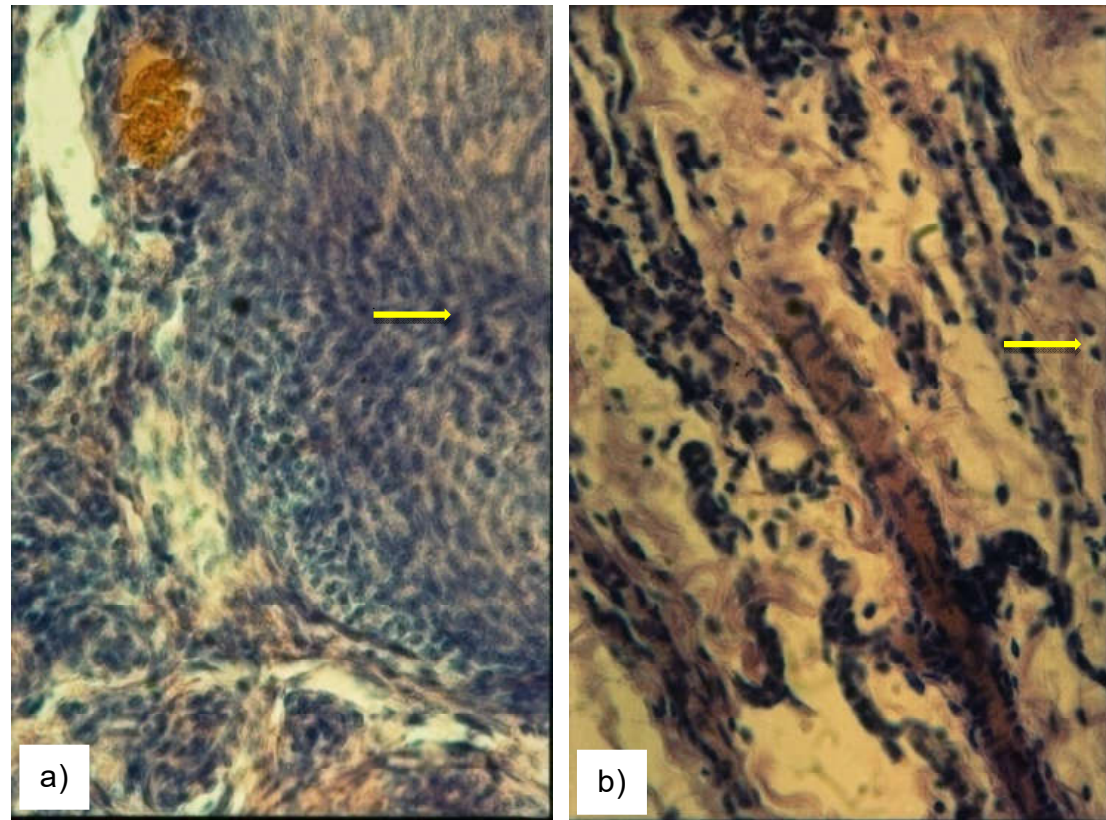

Fig. 4. Collagen fiber growth with the formation of tender sclerosis (yellow arrows). a - Van Gieson method, x200; b - Van Gieson method, x200.

sclerosis of the interstitium, pronounced diapedesis of erythrocytes, marginal standing and diapedesis of leukocytes, numerous accumulations of lymphocytes, macrophages, as well as basophils in the interstitium.

Significant reduction of the thickness of the unchanged adipose tissue area, increase and expansion of the intermediate region was established. Moreover, it increases the number of blood vessels of the microcirculatory bed, which are enlarged and full-blooded. Very enlarged lymphatic vessels. There is diapedesis of leukocytes through the wall of arterioles and venules, capillaries, as well as tender mesh sclerosis.

In the interstitium, a large number of macrophages,

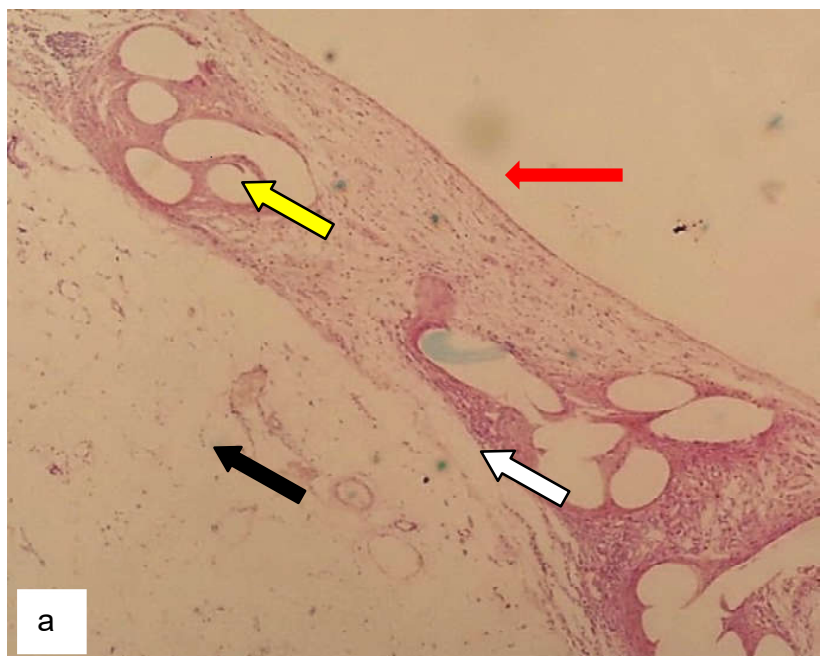

leukocytes and tissue basophilia are located near the vessels of the microcirculatory bed. Changes observed in the dynamics, manifested in the form of an inflammatory process, the signs of which were an increase in the number of vessels, an increase in infiltration of interstitium by macrophages, lymphocytes, tissue basophils, diapedesis of erythrocytes, which tended to increase and achieve the highest magnitude on the third week, collagen fibers, which led to tender mesh sclerosis and then to the development of fibrous tissue and fibrosis.

Experimental study of the influence of alloprosthetics by composite mesh on surrounding tissues. At implantation of a composite mesh on a great omentum of a dog in 3 months after operation its full merging with it was observed. Around the mesh weave, they revealed fibrous tissue filling the cells, forming a single dense structure ("patch") (Fig. 5).

In some places, granulomas of foreign bodies were observed around the elements of the grid, granulation tissue islands were observed. As it matured, it turned into fibrous. Large extraneous granulomas were found around the suture that fixed the graft on the great omentum and not around its elements. Fuchsinophilic collagen fibers and pyroninophilic fibroblasts (collagen synthesis) were found in the newly formed connective tissue, and the elastic fibers were not traced.

The fatty tissue of a great omentum was also drawn into the honeycomb mesh of the polypropylene mesh, which created the idea of its "ingrowth". From the free surface of

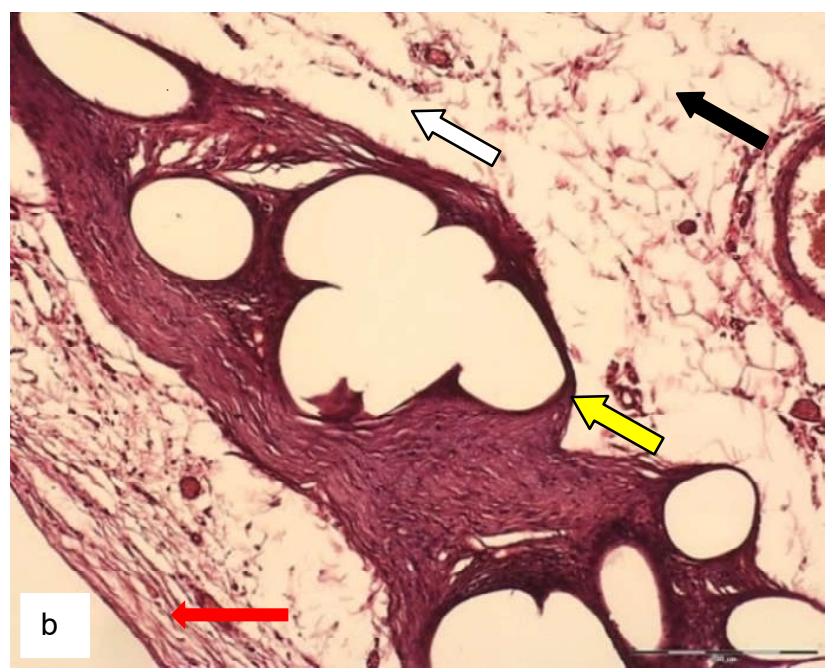

Fig. 5. Fusion of cellulose-coated polypropylene mesh with a great omentum of dog after 3 months after implantation: mesh cavities (white arrows), fibrous tissue "binds" the weave, filling the honeycombs (yellow arrows), great omentum (black arrows), peritoneum on the surface of the formed "patch" (red arrows). a - Brasche method, x40; b - hematoxylin-eosin, x100. 

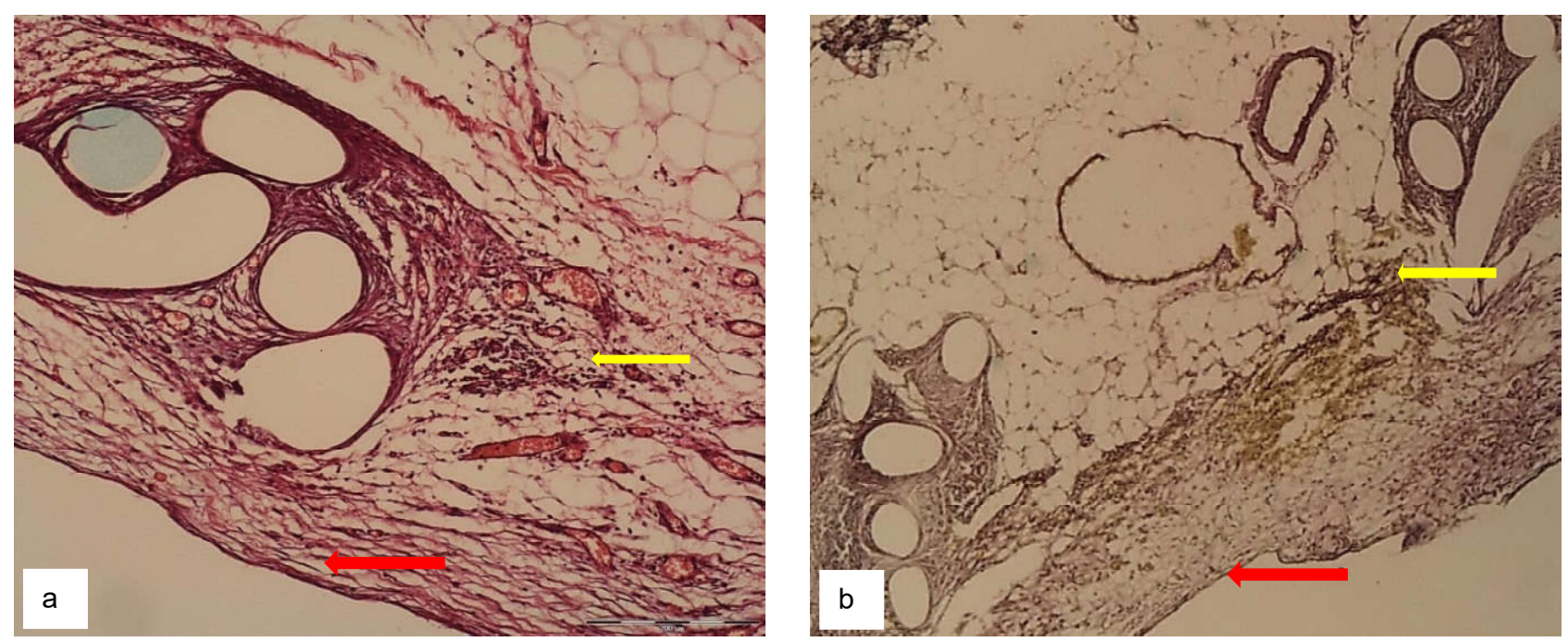

Fig. 6. "Ingrown" adipose tissue of the great omentum (black arrows) into the cells of the implanted mesh and spread by peritoneum that formed the "patch" (red arrows) 3 months after surgery. a - hematoxylin-eosin, x100, b - Verhoff method, x100.
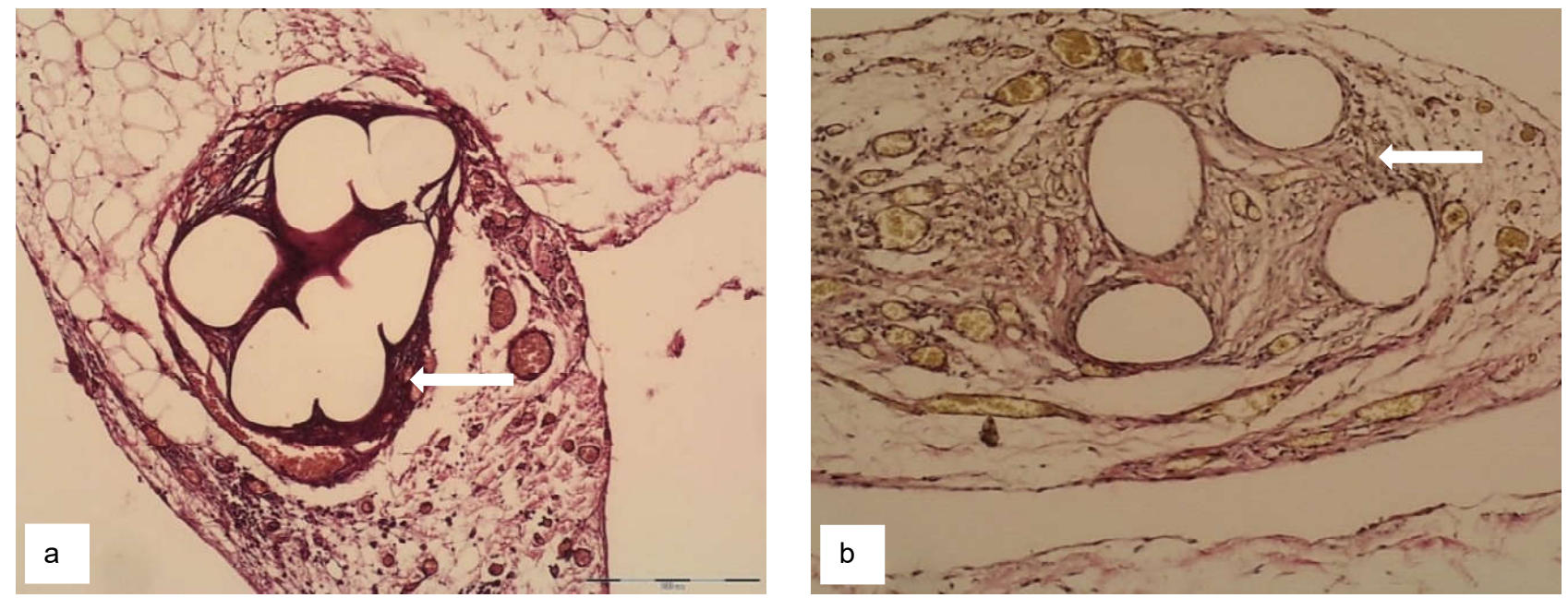

Fig. 7. Multiple full blood vessels (arrows) surrounded by a cavity with elements of implanted cellulose coated polypropylene mesh 3 months after surgery. a - hematoxylin-eosin, x100, b - Verhoff method, x100.

the mesh facing the abdominal cavity, the fat and connective tissues that filled the cells were coated with gel material, which prevented adhesions from forming with the adjacent small intestine loops (Fig. 6).

In the adipose tissue of the great omentum in the implant around the areas of fibrosis in the cells and around the actual mesh elements were observed vasculitis with pronounced lymphoplasmacytic infiltration of the walls of blood vessels and perivascular zones, the marginal standing of leukocytes (neutrophils), which is caused by gel coating of polypropylene mesh.

It should be noted that the tissues around the mesh structure were well vascularized and poorly infiltrated by individual lymphocytes, plasma cells and macrophages (Fig. 7).

\section{Discussion}

According to the morphological analysis of some authors, the use of collagen-treated polypropylene mesh after the plastic defect is accompanied by an acceleration of reparative processes and an improvement in the alterations of the connective, muscular and vascular components of the anterior abdominal wall 4 weeks after intervention [10].

The revealed signs of chronic inflammation with the presence of giant multinucleated foreign body cells in the implanted mesh area served as a basis for the researchers to develop postoperative complications and relapses. In alloplasty by the method "onlay" exudative inflammation prevails, with "sublay" - productive, which confirms the higher efficiency of the retromuscular placement of the mesh implant.

Several authors have experimentally established that intraperitoneal placement of a composite mesh implant with anti-adhesive coating does not cause splicing with internal organs, provides optimal integration into the tissues of the abdominal wall with a slight deformation, promotes the formation of neoperitoneum, without stitching of straight muscles [11]. 
In the study of allografts (polypropylene mesh with and without anti-adhesive coating, polytetrafluoroethylene mesh with nitinol framework), some authors argue for a comparative effect on the level of adhesive process in the study groups of rats. Others indicate that the level of adhesive process in the abdominal cavity when intraabdominal placement of polytetrafluoroethylene mesh with nitinol framework is $34.8 \%$ and $46.3 \%$ lower than the corresponding figure after intraabdominal placement of polypropylene mesh with anti-adhesive and without it $(p<0.05)$.

The commissure in rats that were intraabdominally placed with a polypropylene mesh with an anti-adhesive coating are represented by a loose connective tissue, and when used with polypropylene mesh, are composed mainly of collagen fibers, their structure is unregulated. The introduction of tension free plastic with the use of mesh implants has allowed to solve a number of issues of modern surgery. The variety of mesh implants makes it possible to use new treatments reliably and, in most cases, close abdominal wall defects without reducing the volume of the abdominal cavity. Recently, reports of intraperitoneal onlay mesh (IPOM) have begun to appear, but data on the most effective type of implant are missing [11, 16]. Therefore, we need a new individual approach to the selection of mesh material, its fixation features and location. The use of special nets with their intraperitoneal location can help improve the results of treatment of abdominal wall defects. Implants with anti-adhesive coating when using the IPOM technique provide optimal integration into the tissues of the abdominal wall with a slight deformity, promote the formation of the neoperitoneum and minimal adhesive process in the abdominal cavity [6].

Finding mesh material that meets the requirements of an ideal hernioprosthesis remains an urgent task of treating ventral hernias. In experiments on Wistar rats, the nature of the local proliferative inflammatory response induced by a foreign body was investigated at different terms after implantation of 4 polypropylene, 1 teflon and 1 metal mesh hernioprosthesis from different manufacturers. In parallel with the histological examination of the encapsulated mesh implant, two morphometric parameters of aseptic proliferative inflammation were evaluated, namely: the mass of the connective tissue capsule around the foreign body and its thickness. It has been established that the minimal fibrous capsule is formed after implantation of a polypropylene mesh endoprosthesis within 3 months [10].

According to a number of authors it is believed that pronounced inflammatory reaction is caused by polypropylene implants. The maximum fibrous capsule is formed after implantation of mesh-implant to rats from porous two-layer polytetrafluoroethylene. Poor results are associated with a high incidence of purulent-inflammatory complications in the postoperative wound (up to $49.2 \%$ of cases) and in the postoperative spaces of the abdominal wall [6]. Suppuration of postoperative wounds causes a high incidence of disease recurrences, which, according to various authors, ranges from $14 \%$ to $50 \%$, and after repeated operations there is an increase in their number from $65 \%$ to $80 \%$ [15].

It is believed that special prospects may rely on the creation of prostheses that combine the positive properties of both polyvinylidene fluoride and polypropylene materials. The inflammatory response induced by implantation into the abdominal wall of these prostheses is associated with a minimal adhesive process in the area of polyvinylidene fluoride-based material introduction and more pronounced in the area of polypropylene prostheses. Undoubtedly, the development of implants with such properties is important for the needs of herniologists $[4,13]$.

Despite the above research results, most authors note that with allohernioplasty of giant postoperative ventral hernias, today we have a high postoperative mortality rate, which is $1.3-12.0 \%$ and a significant number of postoperative complications - 20-63\% [7, 17, 19].

In our study, within 3 weeks, changes in the microscopic structure of the omentum were examined after the polypropylene mesh was sewn. Study of histological preparations after 1 week allowed to distinguish two zones: in the first, close to the mesh, an inflammatory process was expressed, which was manifested in the increase, in comparison with the control study, the number of blood capillaries of the microcirculatory bed, thickening of the walls of arterioles, venous plethora, diapause through the wall of the blood capillaries. The omentum adipose tissue was replaced by a coarse fibrous connective tissue that revealed the proliferation of fibroblasts and the spread of collagen fibers, ie, sclerosis was present; in the second, highlighted more than 40 microns, the structure of the omentum was almost indistinguishable from the structure of the omentum in norm.

The study of the drugs 2 weeks after surgery, in addition to the above areas, made it possible to distinguish another - the intermediate zone of tender sclerosis, which separated the two previous zones. After 3 weeks after surgery, the first area with corresponding histological changes significantly expands. The interstitium marked a significant reduction of the second zone. Also, there was a significant increase in the number of microcirculatory vessels, marginal standing of leukocytes, their diapedesis through the vein wall, adhesion and diapedesis of erythrocytes through the capillary wall, a large number of macrophage and lymphocyte clusters, which were subordinated to the lymphoid follicles. Thus, this study confirmed the limited spread of the inflammatory response that made it possible to implant a polypropylene mesh on a great omentum.

In the remote postoperative period (3 months), with the spread of sclerotic changes, there was an enlargement of the composite mesh with surrounding tissues from the side where there was no gel coating. On the other hand, where it was present, sclerotic processes were absent, however, there was a "readiness" for the spread of the inflammatory 
process, which could be manifested after the shelf life of this coating.

Therefore, from the results of the experimental material it is established that irrespective of the type of implant, its adhesion with the surrounding tissues is observed. The largest adhesive processes were observed with the polypropylene mesh, there were no sclerotic processes when using composite meshes and the process depended on the shelf life of the gel coating.

This study requires further accumulation of material to confirm the above findings.

\section{Conclusions}

The polypropylene implant has a greater capacity for

\section{References}

[1]Akoh, J. A. (2017). Management of Incisional Hernias at a Tertiary Centre. International Journal of Surgery Research and Practice, 4(3), 3-7. doi: 10.23937/2378-3397/1410059

[2]Ali, A. M., \& Khalil, M. (2017). Ventral hernias meshplasty: does mesh-implantation site affect the outcome?. Egypt. J. Surg., 36, 69-75.

[3] Chistyakov, D. B., Movchan, K. N., \& Yashchenko, A. S. (2016). Risks of adhesions formation at intra-abdominal implantation into the abdominal wall of mesh prostheses made of ambiguous materials with different bio-energy properties. Bulletin of the Russian Military Medical Academy, 2, 164-169.

[4] Chistyakov, D. B., Yashchenko, A. S., \& Yakovenko, T. V. (2016). Modern possibilities of choice of a method of a gernioplasty at patients with postoperative ventral hernias. Bulletin of the Novgorod State University by name Ya. Mudriy, 1(92).

[5] Deerenberg, E. B., Timmermans, L., Hogerzeil, D. P., Slieker, J. C., Eilers, P. H. C., Jeekel, J., \& Lange, J. F. (2015). Asystematic review of the surgical treatment of large incisional hernia. Hernia, 19(1), 89-101. doi: 10.1007/s10029-014-1321-x

[6] Felestinsky, Ya. P., Lysenko, R. B., \& Smishchuk, V. V. (2016). Estimation of the efficiency of application of varieties of mesh implants in intraperitoneal aloplasty of complex abdominal wall defects. World of Medicine and Biology, 12(1(55)).

[7] Feleshtynsky, Ya., Smischuk, V., Vatamaniuk, V., Svyrydovskyi, S., \& Shupyk, P. L. (2018). Choice of component separation technique in case of giant incisional ventral hernias Materials of Monothematic conference on the state of art in hernia repaire under auspices of the European society. Lviv, Ukraine.

[8] Ferzoco, S., Clara, E. S., Tang, S. W., Hu, J., Tan, W. B., Shabbir, A., ... Gwiti, P. (2015). Mesh \& prosthesis. Hernia, 19, S147. doi: 10.1007/BF03355343

[9] Kawaguchi, M., Ueno, H., Takahashi, Y., Watanabe, T., Kato, H., \& Hosokawa, O. (2015). Transitional mesh repair for large incisional hernia in the elderly. International Journal of Surgery Case Reports, 7, 70-74. doi: 10.1016/j.jiscr.2014.12.023

[10] Kchibekov, E. A., Kohanov, A. V., Kaliyev, D. R., Kudayev, S. V., Bondarev, V. A., \& Serdyukov, M. A. (2018). Peculiarities of the inflammatory reaction of rats on the implementation of contemporary mushroom endoprotese for gernoplasty. Modern Problems of Science and Education, 1, 61-61. the development of adhesive processes, but if the great omentum is shielded from the abdominal organs by the developed method, it is possible to prevent the development of adhesive bowel disease. Composite nets with a one-sided gel coating remain for a long time "ready" for the propagation of the inflammatory process, so it is also necessary to shield it with a great omentum from the intestine. Therefore, no type of prosthetic material guarantees the avoidance of adhesive process in the abdominal cavity in the postoperative period after allohernioplasty of giant postoperative hernias, which indicates the need to use a great omentum on the border between the allograft and the abdominal cavity to prevent the above complications.

[11]. Morawski, J., Miller, G., \& Kallenberger, G. (2015). Novel suture technique for laparoscopic fascial closure and ipom reinforcement. Hernia, 19(2), 124.

[12] Nobaek, S., Rogmark, P., Petersson, U., Hu, S. B., Sun, P., Song, Z. F., ... Chen, F. Q. (2015). Incisional hernia: complications \& quality of life. Hernia, 19(S1), S51-S56. doi: 10.1007/BF03355326

[13] Rastegarpour, A., Cheung, M., Vardhan, M., Ibrahim, M. M., Butler, C. E., \& Levinson, H. (2016). Surgical mesh for ventral incisional hernia repairs: Understanding mesh design. Plastic Surgery, 24(1), 41-50. doi: 10.4172/plastic-surgery. 1000955

[14] Reinpold, W., Schröder, M., Berger, C., Nehls, J., Schröder, A., Hukauf, M., ... Bittner, R. (2019). Mini-or less-open sublay operation (MILOS): a new minimally invasive technique for the extraperitoneal mesh repair of incisional hernias. Annals of Surgery, 269(4), 748-755. doi: 10.1097/ SLA.0000000000002661262

[15] Slater, N. J., van Goor, H., \& Bleichrodt, R. P. (2015). Large and complex ventral hernia repair using "components separation technique" without mesh results in a high recurrence rate. The American Journal of Surgery, 209(1), 170-179. doi: 10.1016/j.amjsurg.2014.02.013

[16] Suwa, K., Okamoto, T., \& Yanaga, K. (2018). Is fascial defect closure with intraperitoneal onlay mesh superior to standard intraperitoneal onlay mesh for laparoscopic repair of large incisional hernia? Asian Journal of Endoscopic Surgery, 11(4), 378-384. doi: 10.1111/ases.12471

[17] Tuveri, M., Tuveri, A., Nicolo, E., Tsuruma, T., Nagayama, M., Nakano, S., ... Chen, J. (2015). Topic: Incisional Hernia - "Difficult case" as specialistic case: real loss of substance, multi recurrences, infections, fistulas, lombocel, burst abdomen, reconstruction of the entire wall. Hernia, 19, S225-36. doi: 10.1007/BF03355359

[18] Yang, G. P. C. (2017). From intraperitoneal onlay mesh repair to preperitoneal onlay mesh repair. Asian Journal of Endoscopic Surgery, 10(2), 119-127. doi: 10.1111/ases.12388

[19] Wadhera, S., Khetan, M., Bhatia, P., John, S., Bindal, V., Matyja, A. \& Kalhan, S. (2015). Incisional hernia: difficult cases 1. Hernia, 19, S93. doi: 10.1007/BF03355333

\section{МОРФОЛОГІЧНІ ЗМІНИ ВЕЛИКОГО ЧЕПЦЯ ПРИ ІМПЛАНТАЦІЇ ПОЛІПРОПІЛЕНОВИХ ТА КОМПОЗИТНИХ ПРОТЕЗІВ ПРИ АЛОГЕРНІОПЛАСТИЦІ Воровський О.О., Шапринський В.О., Садик І.М.}

До теперішнього часу при алогерніопластиці гігантських післяопераційних вентральних гриж зберігається висока післяопераційна летальність і значна кількість післяопераційних ускладнень. Мета дослідження - дослідити можливість 
інтраперитонеального застосування поліпропіленових та композитних імплантатів при алогерніопластиці післяопераційних гігантських вентральних гриж за рахунок вивчення морфологічних змін великого чепця. Досліджено результати хірургічного лікування 146 хворих з післяопераційними гігантськими вентральними грижами. У даній групі хворих алогерніопластика за методом onlay була виконана 22 (15,1\%) хворим, за методом sublay - 46 (31,5\%), за методом inlay - 52 (35,6\%), 3 внутрішньочеревним розташуванням сітки за методом onlay (intraperitoneal onlay mesh) - 26 (17,8\%). У 32 (21,9\%) хворих, що були прооперовані за методом sublay, поліпропіленовий імплантат був відгороджений від органів черевної порожнини великим чепцем, у 22 (15,1\%) хворих, що прооперовані за методом intraperitoneal оnlay теsh, композитний імплантат також був відгороджений від органів черевної порожнини великим чепцем. У 8 (5,5\%) пацієнтів із групи хворих, прооперованих за методом sublay ma у 6 (4,1\%), прооперованих за методом intraperitoneal onlay mesh, на 14-18 добу розвинулися ознаки хронічної кишкової непрохідності, де причиною стала післяопераційна спайкова хвороба. Дослідження впливу поліпропіленового протезу на великий чепець проводили на 8 безпородних собаках та композитного імплантату - на 6 безпородних статевозрілих собаках, котрим було імплантовано композитну сітку, однобічно вкриту оксицелюлозою. Встановлено, що поліпропіленовий імплантат має більшу здатність до розвитку адгезивних процесів. Проте, якщо великим чепцем відгородити даний протез від органів черевної порожнини, то перша зона (активного запалення) поширювалася до 155 мкм (встановлено збільшення чисельності кровоносних капілярів мікроциркуляторного русла, потовщення стінки артеріол, венозного повнокрів'я, діапедез лейкоцитів крізь стінку кровоносних капілярів), друга зона (склерозування) - до 40 мкм (встановлено збільшення чисельності макрофрагів і лімфоцитів, проліферація фрібробластів). Подалі будова чепця майже не відрізнялась, тому при алогерніопластиці за розробленою методикою вдалося запобігти розвитку спайкової хвороби кишечника. Це дослідження підтвердило обмежене розповсюдження запальної реакції, що дає можливість імплантувати поліпропіленову сітку на великий чепець. У композитних сіток відбувалося їх зрощення з навколищніми тканинами з боку, де відсутнє гелеве покриття, а з боку гелевого покриття зберігалася "готовність" до розповсюдження запального процесу (васкуліт з вираженою лімфоплазмоцитарною інфільтрацією стінок судин і периваскулярних зон, крайове стояння лейкоцитів), а тому його також необхідно відгородити великим чепцем від кишки.

Ключові слова: поліпропіленовий протез, композитна сітка, алогерніопластика, великий чепець.

\section{МОРФОЛОГИЧЕСКИЕ ИЗМЕНЕНИЯ БОЛЬШОГО САЛЬНИКА ПРИ ИМПЛАНТАЦИИ ПОЛИПРОПИЛЕНОВИХ И КОМПОЗИТНЫХ ПРОТЕЗОВ ПРИ АЛЛОГЕРНИОПЛАСТИКЕ \\ Воровский О.О., Шапринский В.А., Садык И.Н.}

До настоящего времени при аллогерниопластике гигантских послеоперационных вентральных грыж сохраняется высокая послеоперационная летальность и значительное количество послеоперационных осложнений. Цель исследования исследовать возможность интраперитонеального применения полипропиленовых и композитных имплантатов при аллогерниопластике послеоперационных гигантских вентральных грыж за счет изучения морфологических изменений большого сальника. Исследованы результаты хирургического лечения 146 больных с послеоперационными гигантскими вентральными грыжами. В данной группе больных аллогерниопластика по методу опlaу была выполнена 22 (15,1\%) больным, по методу sublay - 46 (31,5\%), по методу inlay - 52 (35,6\%), с внутрибрюшным расположением сетки по методу опlау (intraperitoneal onlay mesh) - 26 (17,8\%). У 32 (21,9\%) больных, которые были прооперированы по методу sublay, полипропиленовый имплантат был отгорожен от органов брюшной полости большим сальником; у 22 (15,1\%) больных, прооперированных по методу intraperitoneal onlay mesh, композитный имплантат также был отгорожен от органов брюшной полости большим сальником. У 8 (5,5\%) пациентов из группы больных, которые были прооперированы по методу sиblaу и у 6 (4,1\%), прооперированных по методу intraperitoneal onlay mesh, на 14-18 сутки развились признаки хронической кишечной непроходимости, где причиной стала послеоперационная спаечная болезнь. Исследование влияния полипропиленового протеза на большой сальник проводили на 8 беспородных собаках и композитного имплантанта - на 6 беспородных половозрелых собаках, которым была имплантирована композитная сетка, односторонне покрытая оксицеллюлозой. Установлено, что полипропиленовый имплантат имеет большую способность к развитию адгезивных процессов. Однако, если большим сальником оградить данный протез от органов брюшной полости, то первая зона (активного воспаления) распространилась до 155 мкм (установлено увеличение численности кровеносных капилляров микроциркуляторного русла, утолщение стенки артериол, венозное полнокровие, диапедез лейкоцитов через стенку кровеносных капилляров), вторая зона (склерозирования) - 40 мкм (установлено увеличение численности макрофрагов и лимфоцитов, пролиферация фибробластов). В дальнейшем строение сальника почти не отличалось, поэтому при аллогерниопластике по разработанной методике удалось предотвратить развитие спаечной болезни кишечника. Это исследование подтвердило ограниченное распространение воспалительной реакции, что позволяет имплантировать полипропиленовую сетку на большой сальник. В композитных сетках происходило их сращивание с окружающими тканями со стороны, где отсутствует гелевое покрытие, а со стороны гелевого покрытия сохранялась "готовность" к распространению воспалительного процесса (васкулит с выраженной лимфоплазмоцитарной инфильтрацией стенок сосудов и периваскулярных зон, краевое стояние лейкоцитов), а поэтому также его необходимо оградить большим сальником от кишки.

ключевые слова: полипропиленовый протез, композитная сетка, алогерниопластика, большой сальник. 